\title{
A Critical Appraisal of the Concept of Double-Decker Marriage under the Nigerian Family Law
}

\author{
Emmanuel Folayan Ijalana*, Julius Olaseinde Agbana \\ Department of Jurisprudence and Private Law, Faculty of Law, Obafemi Awolowo University, Ile-Ife, Osun, Nigeria \\ Email: ^ijalanaef@gmail.com
}

How to cite this paper: Ijalana, E. F., \& Agbana, J. O. (2021). A Critical Appraisal of the Concept of Double-Decker Marriage under the Nigerian Family Law. Beijing Law Review, 12, 1163-1178. https://doi.org/10.4236/blr.2021.124060

Received: October 25, 2021

Accepted: December 12, 2021

Published: December 15, 2021

Copyright (๑) 2021 by author(s) and Scientific Research Publishing Inc. This work is licensed under the Creative Commons Attribution International License (CC BY 4.0).

http://creativecommons.org/licenses/by/4.0/

Open Access

\begin{abstract}
The paper examined the legal framework with law practices, judicial pronouncements and other statutory legislations relating to family law in Nigeria. This was with a view to undertaking holistic analysis and appraisal of the concept of double-decker marriage under the Nigerian family law. The study relied on primary and secondary sources of information. Constitution of the Federal Republic of Nigeria, 1999 (as altered), various statutes in Nigeria enacted on family law and marriages which include Marriage Act Cap M 6 Laws of the Federation of Nigeria, 2004; Matrimonial Causes Act Cap M 7, Laws of the Federation of Nigeria, 2004; Criminal Law, Cap C 38, Laws of the Federation of Nigeria, 2004; and unstructured interviews, and judicial decisions. The secondary source included books, journal articles, conference proceedings, newspapers and magazines and the internet. Data collected were subjected to content analysis. The study found that there are two systems of marriage, i.e. statutory marriage or customary marriage under which Nigerian couples could contract their marriages, the changing socio-cultural situations in $\mathrm{Ni}$ geria had however, led to contracting marriages under both systems at different time by the same couple (this is otherwise called double-decker marriage). It also found that many such double-decker marriages are contracted illegitimately, in an offending reversed order. The study concluded that the grant of enviable marriage certificate in statutory marriage, carries with it, certain enforceable rights, is only available to the statutory marriage, which accounted for a mad-rush to double-decker marriage and the study therefore recommended the regulation of customary-marriages and demanded similarly the issuance of marriage certificate in customary marriage system.
\end{abstract}

\section{Keywords}

Marriage, Statutory Marriage (Monogamous Marriage), Customary Marriage 
(Polygamous Marriage) and, Double-Decker Marriage

\section{Introduction}

Both the Christian and the Islamic creeds accept marriage as ordained institution from God. This informs why honour is often accorded to family life. Both creeds also declare that a man recently espoused to a wife should not go to war. However, these injunctions have suffered degradation from triviality of marriage in the society.

Marriage exists in different forms and, indeed, under the Nigeria legal system, there are two broad kinds of marriage; namely, the statutory marriage and customary-law marriage. The statutory marriage, denoted as Christian or court marriage, is strictly monogamous and governed by the provisions of the Marriage Act 2004 [MA 2004] and Matrimonial Causes Act 2004 [MCA 2004]. The customary law which is mainly polygamous, is however divided into strict customary-law marriage and Islamic-law marriage. While the Islamic law is concretised in a written form, the customary is predominantly unwritten. Though a couple is entitled to choose under which of these systems they may want to celebrate their marriage, couples in the southern Nigeria often opt for a celebration of under both systems of marriage; that is, the customary marriage and the statutory marriage. Where this occurs, the contraption is referred to as "Double-decker Marriage" (Okoro \& Wesey, 2014). It is this contraption that has become the subject of our engagement in the current work.

Examining the cultural practices and Family Law in Nigeria, this paper, apart from its introduction, shall concentrate, as much as possible, on the conceptualisation and meaning of such terms as marriage, statutory marriage (monogamous marriage), customary marriage (polygamous marriage), and double-decker marriage, legal framework for double-decker marriages; the nature and operation of double-decker marriage; double-decker marriage in Nigeria: causes, implications and effects as well as conclusion and recommendations.

\section{Conceptualisation and Definitions of Terms}

Misuse of word is a common cause of misunderstanding and, to avoid inherent obstruction to flow of comprehension, we shall endeavour, for proper understanding of the subject, to conceptualise and define the key words which include marriage, statutory marriage (monogamous marriage), customary marriage (polygamous marriage), and double-decker marriage.

\subsection{Marriage}

The word "marriage" has different meanings to different people; so also do the lexical definitions. The word "marriage" is defined by Oxford Languages and Goggle as the legally and formally recognized union of two persons as partners 
in a personal relationship (historically and in some jurisdiction, especially a union between a man and a woman). Same word is construed by Merriam-Webster Dictionary to mean, the state of being united as spouses in a consensual and contractual relationship recognised by law; the mutual relations or married persons: wedlock; the institution whereby individuals are joined in marriage; or an act of marrying or the rite by which the married status is effected especially the wedding ceremony and attendant festivities or formalities. The Black's Law Dictionary, however, defines marriage as the legal union of a couple as husband and wife (Garner, 2004), while the Cambridge Advance Learner's Dictionary defines marriage as a legally-accepted relationship between two people in which they live together, or the official ceremony that results in this (Mclntosh, 2013).

The above lexical definitions appear too vague, incomprehensible and not too functional for our purpose, as relates to passive use of gender specificity capable of corrupting African moral. Except the Oxford Languages and Google that uses, vaguely though, gender specificity inconceivably, most lexical definitions merely adopt species at the risk of gender. This is understandably so, considering the introduction and acceptance of same-sex marriages (lawful and marriage consisting of two person of the same sex) into the world's social order and its adoption constitute a stern rebuff of gender discrimination. This being so, recourse has to be made to the works of eminent scholars as well as statutory and judicial interventions.

Nwogugu (1985), in his treatise, Family Law in Nigeria, defined marriage as:

... a universal institution which is recognized and respected all over the world. As a social institution, marriage is founded, and governed by the social and religious norms of the society. Consequently, the sanctity of a marriage is well-accepted principle in the world community. Marriage is the root of the family and of the society (Nwogugu, 1985: 1xxviii).

The use of the phrase "the root of the family and of the society" by Nwogugu (1985) actually connotes spousal union of a man and woman, since the root of family is expectedly procreative productivity. Sagay (1999) adopted the judicial interpretation in Hyde $v$ Hyde which defined marriage as the voluntary union for life of one man and one woman to the exclusion of all others (Sagay, 1999).

Gujo (2019) avers that it is universally accepted that marriage, being a union of man and woman, involves two persons of opposite sex. Thus, sex constitutes an essential determination of marriage relationship. In establishing the validity of a marriage, it must be proved that the persons involved are man and woman (Nwogugu, 1985: p. 3). Such marriage can be monogamous or polygamous, depending on the number of women which the marriage system accommodates.

\subsection{Statutory Marriage (Monogamous Marriage)}

A statutory marriage, otherwise called the monogamous marriage, is predicated on a family relationship between a man and a woman. It is also referred to as Christian marriage which is statutorily defined by section 3 of the Criminal 
Code Cap 38 Laws of the Federation of Nigeria, 2004 as a marriage recognised by the law of the place where it is contracted as the voluntary union, for life, of one man and one woman to the exclusion of others. Marriage contracted under the statute prohibits either of the spouse to conduct another wedding with any other person during the continuance of such statutory marriage.

\subsection{Customary Marriage (Polygamous Marriage)}

Customary marriage is a marriage contacted under the native law and custom, otherwise known as customary law (Nwogugu, 1985: p. 3). Customary marriage also extends to marriages conducted under the Islamic law (Olokooba, 2007: p. 196). These two systems of marriage have common similarities, not only because they are both customary marriages, but also because both allow the practice of polygamy. Accordingly, polygamy in Nigeria is, customarily, institution with characters and practices are regulated by customary law. Customary law, it must be noted, is devoid of a single uniform system prevailing throughout Nigeria. Accordingly, Nwogugu (1985) avers that "the term covers a multiple of systems of law which differ from one locality to another". Putting this differently, Nwudego (2016) posits that:

There are many customary forms of marriages as are diverse ethnic group in Nigeria. Customary marriages are inter-twinned with African traditional religious and beliefs ... which expresses a firm belief in reincarnation (Nwudego, 2016: pp. 49-60).

Expectedly, therefore, customary law possesses three unique features; namely, it is unwritten; it must be a mirror of accepted usage in the area where it is applied, and its rules change with time (Nwogugu, 1985: lxxxi). Customary marriage is a voluntary union for life of one man and one or and several wives though the number of wives, in the case of an Islamic marriage, is limited to four (Nwogugu, 1985: lxxvii). Thus, Nwogugu (1985) cautioned against misunderstanding the nature of polygamy when he posited that:

The mere fact that, at a given moment, he has only on wife does not affect the character of the marriage so long as the capacity of taking more wives is retained. Generally, there is no limit to the number of wives a husband could take under the polygamous system [except that Islamic law limits the number of wives to four]. This invariably depends on his affluence (Nwogugu, 1985: 1xxvii).

As earlier stated, a couple is at liberty to conduct either a polygamous or monogamy marriage. However, cultural inclination in Nigeria and, in some African countries, has resulted in a contraption otherwise called "double-decker marriage", at which instance, the couple celebrates both the customary marriage and the statutory marriage, for reasons that would soon be considered later in this chapter. It, however, suffices to say at this juncture that this sort of a marriage is the vouge in Africa. What then is "double-decker marriage"?

\subsection{Double-Decker Marriage}

The phrase "double-decker" marriage is not found in the dictionary. The closet 
item to it in any dictionary is its component "double-decker" which is defined by Merriam-Webster Dictionary as something that is double-decked. The phrase, in Collins English Dictionary, is defined adjectivally as items or structures having two layers or levels inside of one. It was in the sense of the latter definition that Onoka (2003) used the term to describe a marriage contracted under two regimes:

Double-decker marriage involves celebration by the same couple of a marriage under one system and their subsequent marriage under another system ... (Onoka, 2003: p. 143)

The needless efforts put into this contraption that is of no effect made some scholars conceive double-decker marriage as a chameleonic type of marriage which combines the flavour and characteristics of both customary and statutory marriages domiciled in the same family (Olokooba, 2007: p. 196).

\section{Legal Framework, Nature and Operation of Double-Decker Marriage}

In the first aspect of this section, a number of legal frameworks for regulation of marriages have been identified which include the Constitution of Federal Republic of Nigeria, 1999 (as altered), which, by its s37 preserves the right to private life and home; the Marriage Act 2004 and; Marriage Causes Act 2004 which make provisions for the contraction, celebration and dissolution of marriages. Similarly, the Married Women Property Act contains extensive provisions for protection of marriage, too. Customary and Area Courts Law which provides for the customary courts' jurisdiction over causes relating to issues arising from marital relationship and dissolution of such marriages contracted under native custom and law in Nigeria; sharia laws relating to matters of Islamic marriage and issues arising therefrom, family relationship including family succession, devolution of family property, spousal separation and dissolution of marriage. The above laws contain general provisions relating to relationships and rights in the family. A major law which makes extensive specific provisions for the validity of double-decker-marriages is the MA 2004 and MCA 2004. These Acts sustain the preservation of double-decker marriage in Nigeria while setting out circumstances under which marriages celebrated with the parties' acquiescence are to be considered null and void.

To this end, Marriage Act 2004 s33(1), s35, and s47 are apposite. For the avoidance of doubt, these sections provide as follows:

s33(1) No marriage in Nigeria shall be valid where either of the parties thereto, at the time of the celebration of such marriage, is married under customary law to any person other than the person with whom such marriage is had;

s35 Any person who is married under this Act, or whose marriage is declared by this Act to be valid, shall be incapable, during the continuance of such marriage, of contracting a valid marriage under Customary law, but, save as aforesaid, nothing in this Act contained shall be affect the validity of any marriage con- 
tracted under or in accordance with any customary law, or in any manner apply to marriages so contracted. And;

Marriage Act 2004 s47 then prescribes the penalty where the above is breached. Thus, it provides that: "whoever, having contracted marriage under this Act, or any modification or re-enactment thereof, or under any enactment repealed by this Act during the continuance of such marriage (and) contracts a marriage in accordance with customary law shall be liable to imprisonment for five years".

This provision expressly allows the validity of both the customary marriage earlier conducted by the parties and the statutory marriage subsequently contracted by the same couple. The provisions of the section 182 of Evidence Act, 2011 relating to non-compellability of witnesses and the provisions of section 36 of the Criminal Code, creating rights for husband and wife, are also apposite, in the circumstance. The impacts of case-law and judicial intervention which constantly shape the marriage law and double-decker marriages also add valour to the legal framework.

Notwithstanding the above legal protection for the practice of double-decker marriage, it is noteworthy that an acceptable double-decker marriage has its order. The customary marriage must precede that statutory marriage. The proceedings for the two marriages must not be held simultaneously or about the same time or thereafter. This is because MA s47 outlaws the contract of customary marriage to any person either between any of the couples or any other person out there. The section prescribes the punishment of five years imprisonment. The pathetic woe of double-decker marriage in Nigeria is that about 30 per cent of double-decker marriages contracted constitutes criminal proceedings by reason of the order of proceedings of such marriages being wrongly reversed. Most couples run early enough in the morning to conduct the statutory marriage and, thereafter, conduct the customary marriage perhaps with the reception of the statutory marriage, either together or as different proceedings. This is wrong in law because after the statutory marriage is contracted, no other marriage, either statutory or customary, is allowed any longer either between the couple or with either of the with any other person, Under the Nigerian Marriage Legislation, the couple risk a five-year imprisonment. The import of this part is to bring to the attention of the readers or students the proper order of proceedings in a double-decker marriage to avert being victimised in one's own engagement.

The nature and operation of double-decker marriage is another issue that would need be examined. A marriage contract differs fundamentally from mercantility. This is because a marriage does not affect the parties alone; it affects also the society to which they belong (Nwagbara, 2004: pp. 52-62). The formation of a marriage has with it the introduction of the law regulating spousal relationship. As earlier noted, statutory marriages are predominantly monogamous while customary marriages are potentially polygamous (Olokooba, 2007: p. 196). The type of marriage contracted by the couple shapes the behavioural patterns of 
the parties involved, revealing its nature and operation. It is on this ground, therefore, that the nature and operation of a double-decker marriage shall be examined briefly hereunder.

In the first instance, double-decker marriage is consequentially a monogamous marriage. Conceivably, a double-decker marriage is a contraption of two marriages, each having varying indications. Double-decker marriage, as already known, connotes the celebration of two different marriages at two different periods through different celebrations by the same couple. The earlier marriage being customary marriage, is potentially polygamous in nature and, the latter, essentially a monogamous marriage. The latter statutory marriage, however, alters the traits or potentiality of polygamy and replaces same with its own inherent traits; that is, the monogamy's incidents and nature. A double-decker marriage lacks the capacity to sustain the existing propensity towards polygamy by reason of superimposition of restraints during the continuance of the latter marriage. It is strictly monogamous and, where the husband intends marrying another wife during the subsistence of the marriage, he must necessarily seek an outright dissolution of the entire double-decker marriage; he cannot reconvert the marriage to a polygamous marriage by just importing another wife as that would tantamount to bigamy (the Criminal code s370).

Again, double-decker marriage admits duality of mixed features. Contrary to the assumption that the features of customary marriage are wholly overtaken by the latter statutory marriage resulting in the customary marriage being spent by its effluxion and, thereby, becoming subsumed into the statutory marriage. The contraction of subsequent statutory marriage still leaves spouses with practices associated with the earlier customary marriage except the preclusion from importing the second wife into the home. Its monogamist's features are sometimes an expression of hypocritical fallacy. Invariably, double-decker marriages could not conform to the practice of monogamy absolutely (Ojogbo, 2011). Investigation into practices in double-decker homes reveals that many husbands in double-decker marriages still engage in inordinate relationship or secretive inordinate extramarital marriage relationship where they keep other homes for other women who are strange to their matrimony (Krenawia, 2004). Other features, including external interference and intervention; couple's families' influence; individual claim of property; cross end interest and; the stress, fear and disparity generally experienced in polygamous home with varying degrees and types of emotional difficult such as anger, jealousy, competition, loneness, unhappiness, and lack of intimacy with their spouses are again common among spouses of double-decker marriages (Ekerbicer, Resim, Efe, Bahar, Altunoren, Kucukdumaz, \& Benlioglu, 2016).

The point here is better illustrated with the cases of Ogunmodede $v$ Thomas and Osho \& Ors. $v$ Philips \& Ors. In Ogunmodede $v$ Thomas, the deceased had married under the Act and had one issue, a female, called Patience Ajibabi. During the subsistence of the marriage, the deceased had 16 other children from 
different women. He openly acknowledged these children before his matrimony. His legitimate wife and his daughter, Patience, also accepted these children and treated them as co-owners of the estate of the deceased. A similar case of same experience and practice is the case of Osho \& Ors. v Philips \& Ors, where the facts were that the plaintiffs/respondents had claimed that, although their mothers were never married to the deceased and that they were born during the subsistence of a statutory marriage to the mother of the defendant, they (the plaintiffs) had been in the house of the deceased and were christened by him, in the presence of the defendant's mother and they had lived together with the defendant in the deceased's house.

\section{Rationales and Implications for Double-Decker Marriage in Nigeria}

The evolutionary trend arising from the acceptance and adoption of double-decker marriages in Nigeria has created fundamental issues and problems and, to ensure a proper understanding of its concept, there would be need to examine these issues and problems in the light of the rationales, implications and effects of double-decker marriage in Nigeria.

The subscription to double-marriage in Nigeria is at the high level, leaving it at a ratio of 8:10 in all statutory marriages conducted. Given the huge amount of money expended in celebrating two different marriages under two systems of law, despite the attendant upsurge of divorce at close interval, one may ask the reason behind the mad-rush to its subscription when either of the two marriages contracted in a double-decker would suffice?

\subsection{The Rationales for Double-Decker Marriages in Nigeria}

Various reasons have been advanced for subscribing to double-decker marriages. The foremost reason is the inseparable clinch to one's native custom and ancestral belief. Children grow up in Africa, with the value of ensuring respect for parents and building reinforcement against deviant elopement. Children have, by early social education, been taught the injunction of promoting parental joy which, according to religious custom of the people, brings blessings from God. Most parents approve of customary marriage in preference to the statutory marriage which they see an unsolicited heritage of neo-imperialism. Aside from this, the need for social support and intervention that would add social value to marriages often prompts couples to celebrate the customary marriage. This is without prejudice, however, to a celebration of statutory marriage thereafter, notwithstanding the emergence of education and its impact on the Nigerian society.

In a lecture delivered by Morgan C., Chief Justice (as he then was), he posited that:

But I submit that neither a Christian Yoruba girl nor a (Hausa) Muslim girl regards herself as being properly married ... Under any circumstance and until such part of the non-fetish part of marriage, in accordance with native law and culture, as are still subsisting, have been performed (Morgan, 1965). 
The above informs why most statutory marriages contracted outside Nigeria by the diaspora couples would still undergo, in absential though, a traditional marriage before their people about the same time in Nigeria, placing vividly the photographs of the couples at the venue to represent their presence.

Following the belief in the imperativeness of their tradition, another reason people engage in double-decker marriage is that there is no law presently forbidding the practice in Nigeria leaving the people to elect a choice. In addition to this is the search for legal force and security backup for an earlier customary marriage as a result of the non-codification of customary law marriage in the Nigerian legislation. Despite the foregoing, scholars have argued that the operation of double-decker marriage is associated with varying issues and problems that must be appreciated by the people (Sagay, 1999: p. 144).

In addition to the above reasons is the need to guide against polygamy. As earlier noted, customary marriage is potentially polygamous in nature. The educated female class sees double-decker marriages as a tool for avoiding polygamy. Most educated Nigeria men who get married to educated women undergo double ceremonies. First, they perform the marriage according to local laws and custom which is usually followed by church and religious marriage which is, in fact under the Marriage Act. But educated women find no security in marriage according to local law and custom which is potentially polygamous even when if the man promises to keep the marriage monogamous.

Besides, the need to obtain official certificate for record purpose is another reason people embark on double-decker marriage. Summing up the relentless impulses associated with the rationale for double-decker marriages in Nigeria, the view of Nwogugu (1985) hereinunder captured remains essentially apt.

It is a common practice in Nigeria for parties who intend to contract a statutory marriage to marry first under the customary law before the solemnization of the statutory marriage. This practice may be explained by the fact that though western civilization and western culture have permeated the Nigeria society, most people, even the most sophisticated understandably regard themselves as bond by the customary law of their marriages. The Nigerian Marriage Act have given validity to this practice by enabling persons who are married under customary law to marry each other under the statute (Nwogugu, 1985).

Having settled the causes of double-decker marriage, it is necessary to examine the implication and effect of such marriages in Nigeria.

\subsection{Implications of Double-Decker Marriage}

As it has been observed earlier, in double-decker marriage, there are two marriages so contacted at different for a howbeit by the same party. What is the legal effect of those multiple marriages? In answering this question, recourse will be had extensively to statutory provisions and judicial pronouncements of courts in Nigeria. The legitimacy of double-decker marriage is not in doubt since it is permissible by law and there is nothing, either customarily or statutorily, prohibiting its existence. Nigerian law preserves the earlier customary-law marriage 
contracted by the same party before contracting a statutory marriage and, thereby, expressly validates same. For the avoidance of doubt, MA 2004 s33(1) provides that:

No marriage in Nigeria shall be valid where either of the parties thereto, at the time of celebration of such marriage, is married under customary law to any person other than the person with whom such marriage is had.

This can be said to be an enduring legal framework for double-decker marriages in Nigeria. Having found that both marriages, in double-decker marriages, are legitimate, what then is the priority and implication of this? This question was positively answered in Jadesimi $v$ Okotie-Eboh \& 2 Ors, where the supreme court held that:

It is a matter of common knowledge that most people in Nigeria who contract marriages under the Marriage Act undergo a form of customary marriage as matter of practice and adherence to the custom of their fore fathers ... it is never intended by the practice that the marriage under the Marriage Act should nullify the customary marriage ... but rather it would supplement the practice and custom. The parties are however aware that by applying the Marriage Act to their relationship, their marriage would become monogamous ... (Jadesimi v Okotie-Eboh)

As a matter of fact, though the Supreme Court by the above judgement have been critiqued for speaking from both sides of the mouth before coming to its decision of nullifying a will made in 1947, during the dependence of a customary marriages contracted in 1942 just because the will was made before the subsequent statutory marriage in 1961, when neither the will at nor the Marriage Act precluded the customary marriage made in 1942 as invalid as a result of the subsequent statutory marriage of 1961 . The criticism became rife when taking into consideration, the community reading of the MA 2004 s33(1), which expressly preserved the validity of the earlier customary marriage of 1942 combined with the reasoning of the court on the legitimation of same. The best effect derivable from the above Supreme Court holding is that it identified that the subsequent statutory marriage did not nullify the customary law marriage earlier contracted, but rather supplemented same. This means that all that was necessarily incidental to the marriage contract under the customary law are still in force except that the potentiality of polygamy, inherent in customary marriages, has ceased to operate during the continuance of the statutory marriage, otherwise it will expose the person doing that to criminal sanction under section 47 of the Marriage Act s 47.

The confusion created by the decision in Jadesimi $v$ Okotie-Eboh appears to have provoked family law jurisprudence to identifying two main schools of thought or three theories propounded for purposes of deciphering what the status of the earlier customary-law marriage in a double-decker marriage should be. These theories are the (a) conversion theory and; (b) co-existence theory.

\section{1) Conversion Theory}


The "conversion" theorists posit that, once couple who earlier contracted customary marriage undergoes a subsequent statutory marriage, the earlier customary marriage automatically converts its legality to a latter statutory marriage. Thus, it was held in Odive v Nweke Obor \& Ors (1973) ECSNLR 733 at 735, that:

... the two marriages do not coexist, a customary marriage merges with the ordinance marriage and loses all its distinction and characteristics, its legal incidence and consequences...customary marriage cannot therefore create one set of legal rights and duties and the ordinance marriage, another with respect to the same persons at the same time (Odive v Nweke Obor\& ors (1973) ECSNLR 733).

If by the subsequent marriage, the customary marriage has thereby been converted as claimed in Odive $v$ Nweke Obor's case, what happened then at the termination of such subsequent marriage by divorce? In the earlier case of Teriba $v$ Teriba \& Rickett, it was held that:

The true position is that the customary marriage is converted by the Act Marriage which in effect, supersedes it. Therefore, if the Act Marriage is subsequently dissolved the customary marriage cannot revive (Teriba $v$ Teriba).

This indicates, therefore, that the termination of subsequent marriage by divorce would need a petition to be filed in the High Court, which is the court seised exclusively with original jurisdiction to dissolve statutory marriages (Marriage Causes Act 2004 s2).

Eminent Nigerian scholars appear to have supported the views of the "conversion theory" proponents. On this note, while postulating on the effect of customary marriage, followed by a statutory marriage between the same parties, Professor Sagay, contrasting Oseni v Oseni and Oshadiya with Akparanta v Akparanta, insists that:

The weight of authority is of the view that the customary marriage is converted into a statutory marriage. In order words, the statutory marriage assimilates the customary marriage, eliminates all its incidence and substitutes its own incidence (Sagay, 1999).

Similarly, in his submission, while answering the question, whether the statutory marriage supersedes the previous customary law-marriage or the customary-law marriage is merely put in abeyance, or both marriages coexist, Nwogugu posits that:

To answer the question earlier raised the correct position is that the subsequent statutory marriage supersedes a previous customary law union. Support for this view is found in two legal principles. First, the relationship into which parties enter by solemnizing a statutory marriage is one which is unknown to customary law, therefore, a different system of law will apply to the situation. Second, marriage under the Marriage Act clothes the parties to it with rights and obligations which are unknown to customary law (Nwogugu, 1985: p. 67).

It is sufficient to conclude that the indices for accessing what theory is being proposed is the legal consequences of the customary marriage after contracting subsequent statutory marriage. It is on this note that the conversion theorist in- 
sists that, as soon as a subsequent statutory marriage is conducted the earlier customary marriage automatically converts all its legality to a statutory marriage. If this claim is correct, then it means that, having had its legality converted to the subsequent statutory marriage, there is nothing left of the earlier customary marriage to be revived after dissolution of the statutory marriage.

\section{2) Coexistence Theory}

In apparent opposition to the "conversion" theorists, the "coexistence" theorists posit that there are two marriages forming the double-decker marriage that both marriages, the customary marriage being the first and the latter statutory marriage, coexist and are each legal and valid. To the "coexistence" theorists, termination of a double-decker marriage would demand that a petition be brought to the High Court for dissolution of the statutory marriage while the customary court marriage would need be dissolved through the instrumentality of the magistrate or customary court. This school further proposes that a dissolution order by the High Court merely dissolves the statutory marriage and not customary-court marriage on which the High Court has no jurisdiction. Thus, in Afonne $v$ Afonne, it was held that:

Where two legally recognized marriages are involved, the party seeking dissolution and a decree of divorce should clearly specify which marriage or marriages he or she wants dissolved (Afonne v Afonne, 1975: pp. 168-169).

The principles giving vent to the above Afonne's decision seems not to have been hidden from those exercising legal reasoning. In an earlier case of Ohochuku v Ohochuku, where the parties had contracted a potentially-polygamous marriage in Nigeria and had a subsequent statutory marriage ceremony in England. On a petition for divorce, the court clearly identified the two marriages; that is, the customary-court marriage which was purely polygamous and the statutory monogamous marriage, and inclined to dissolve only the statutory marriage. It was the holding of the court that:

The Nigerian marriage must be regarded as a polygamous marriage over which the court does not exercise jurisdiction. I therefore pronounce a decree... for the dissolution not of the Nigerian marriage but of the marriage in London. I am told that in fact that would be effective by Nigerian law, as at present, as understood to dissolve the marriage but that forms no part of my judgement; that is for someone else to determine and not for me (Ohochuku v Ohochuku 1960).

From the above pronouncement, it is sterling clear that, contracting a double-decker marriage is permissible and the dissolution of one of the double-decker marriages where the attention of the court is drawn to the other, may not be sufficient for the dissolution of both marriages. The court's expectation, having dissolved the statutory marriage, is that the customary-court marriage is alive and would need to be dissolved separately possibly in Nigeria. This, therefore, indicates that a marriage once contracted still subsists until when necessarily dissolved. Hence, Ohochuku couple still remains in the eye of Nigerian law, validly and legally married though the statutory marriage has been dis- 
solved, until the customary law marriage so recognised is actually dissolved.

Compared against Odive v Nweke Obor \& Ors. where the court hinges its decision on the probable confusion holding otherwise would cause. As the court asserted further in Odive's case that:

[That] would lead to a ridiculous situation where the husband would claim that he was entitled under customary marriage to a plurality of wives while on the other hand, the wife would insist on the exclusion of every other person based on the ordinance's marriage (Odive v Nweke Obor\& Ors.).

Reconciling the two theories seems contentious, in that an important aspect of customary-law marriage is the payment of bride price which, until it is returned, there is a presumption of marriage still in existence. Such burden cannot necessarily be resolved only because a subsequent a marriage the party undergoes has been dissolved. In this light, eminent scholars identified this duty as regards the return of the bride price, notwithstanding what subsequent marriage was superimposed after the earlier customary marriage was contracted. On his part, Nwogugu (1985), in his radical assessment of whether or not the obligation of returning the bride price was compellable, propounded two possible concepts that must be resolved to know whether or not the husband retains his customary-law right under the earlier union to reclaim the bride price, when he asserted that:

But it seems that the answer depends on the characterisation of the husband's claim for a refund of bride price as either a matrimonial or contractual right. If the right is regarded as the matrimonial right, then on principle its enforcement will be lost by the conversation of the customary law marriage into a statutory one. The effect of the conversion is to substitute the matrimonial rights under the statutory marriage, and there is neither the obligation to pay it nor the right to claim it refund under that system (Nwogugu, 1985: p. 68).

Rightly has Nwogugu (1985) appreciated that bride price was not a function of statutory marriage and there was neither the obligation to pay it or the right to claim its refund. This, I think, is a good reason the dissolution of statutory marriage cannot restrain the parties from attending to such fundamental foundational basis of the very existence of their relationship (which includes the bride price and other ancillary issues). It is a life issue in the customary marriage, as rightly held in Ohochuku's case, a matter which the High Court (sitting as a court of first instance) has no jurisdiction to decide and, therefore, they are to be left for the customary law court to decide. This becomes obvious when, as Nwogugu (1985) well appreciated that, the bride price paid was a consideration for the customary-law marriage's contract entered into, which therefore constituted a contractual right. We submit, therefore, that marriage is a contractual relationship entered into by the parties. The fact that bride price is a contractual right demand that a party reneging from such a contract is under an obligation to return the consideration received for the marriage contract. This explains while the Ohochukwu's decision is preferred because dissolving the statutory marriage is all that the High Court can do. Apart from the dissolution of the 
marriage, there remain a lot of issues to be settled arising from the customary-court marriage's contract which includes the payment and claim of bride price and many other matters arising basically from the customary marriage. The parties cannot close their eyes from these issues which must necessarily be submitted to the customary court to decide. It is on this note that I consider the further dissolution of the customary court marriage necessary, even after the dissolution of the statutory marriages.

\section{The Conclusion and Recommendations}

A double-decker marriage is a lawful union of parties built on the celebration of two different marriages of different systems by the same couple who patronised the latter statutory marriage as security against polygamous practices. Couple's exploitation of statutory marriage is for enforcement of rights which are only legally enforceable under the statutory marriage. For instance, the enforcement of cohabitation and conjugal rights as well as maintenance and settlement of property in the event of divorce, are necessary rationale while couples who earlier contracted customary-law marriage often result to subsequent statutory marriage which essentially prohibits polygamy. The contraction of two marriages under different systems, no doubt, provokes some fundamental legal problems bordering on the legal status and priority as necessary incident for termination of marriage. Attempt in resolving these problems has resulted in the propounding two different theories; to wit, the conversion theory which posits the merger of the two marriages into statutory monogamy marriages which change the legality of the earlier customary marriage while the other, with a divergent position in coexistence theory, posits that a marriage once contracted remains in force until its dissolution. It is the claim of coexistence theory that the two marriages coexist only to the extent that polygamy is put in abeyance during the subsistence or continuance of the statutory marriage subsequently contracted.

Considering the seemingly-irreconcilable contentions and other problems associated with double-decker marriages in Nigeria, the following recommendations are proffered:

1) Creating public awareness for Nigerian citizens on the fact that, to all intents and purposes, customary-law marriage is a legal marriage. It is equally important, as the statutory marriage. Such awareness will avail them adequate knowledge that statutory marriage is only one of the two forms of marriage lawfully acceptable in Nigeria. This awareness may be through the mass media; that is, print, air and social media; enlarging the course content of Social Study subject in the Nigeria primary, secondary and tertiary education systems, is also essential. It is also necessary that family education counselling centres should also be established in the schools, churches and youth recreation centres to give ample opportunity to those who will need to seek clarification and counselling on marriage laws in Nigeria as may be appropriate. In addition, there is need to organize regularly periodic lectures and workshops, on the core value of family 
and marriages, for marriageable youths. This will avail the opportunity of setting the order of proceeding during double-decker marriages.

2) Legislative intervention and law reform on liberalisation of family and marriage law in Nigeria towards recognising other systems of marriage in Nigeria are also suggested. Similarly, bye-law that would regulate customary-marriage proceedings in Nigeria will need to be introduced. Such bye-law may make provisions for customary-law marriage certificate that could be used for both official and record purposes, in lieu of statutory marriage certificate.

3) The National and State Houses of Assembly should make necessary laws that would resolve contentious legal issues and theoretical conflicts currently noticeable in the Nigerian marriage system. Also, the judiciary should endeavour to find an enduring solution to conflicting rulings of courts on priority and status of marriages associated with double-decker marriages.

4) Similarly, there should be introduction of law to curb extravagant spending or unnecessary wastage on celebration of multiple marriages.

5) The Nigeria Criminal and Evidence Law should be amended to liberalise the rights and privileges accorded under the Nigerian law to couples who contract statutory marriage. Such rights and privileges should be extended to couples of other systems of marriage.

It is hoped that the above recommendations would, by no little means, promote congenial harmony to Nigerian families which are seen as the very foundation of our existence as a nation.

\section{Conflicts of Interest}

The authors declare no conflicts of interest regarding the publication of this paper.

\section{References}

Afonne v Afonne (1975) FSCSN 159.

Akparanta v Akparanta (1972) 2 ECSLR 779.

Chinwuba, N. N. (2016). Interaction of Customs and Colonial Heritage: The Impact of Marriage and Children in Nigeria. Anthropos, 111, 49-60.

https://doi.org/10.5771/0257-9774-2016-1-49

Collins English Dictionary, Double-Decker Definition and Meaning. https://www.collinsdictionary.com/dictionary/english/double-decker

Ekerbicer, H. C., Resim, S., Efe, E., Bahar, M. R., Altunoren, O., Kucukdumaz, F., \& Benlioglu, C. (2016). A Comparison of Sexual Function, Psychological Status and Socio-Demographic Characteristics of Turkish Men within Polygamous and Monogamous Marriages in Turkey. Balkan Medical Journal, 33, 383-389.

https://www.ncbi.nllm.nih.gov/emc/articles/PMC5001814/* ! po $=35.00$

https://doi.org/10.5152/balkanmedj.2016.16459

Garner, B. A. (2004). Black's Law Dictionary(8th ed.). Thomson West.

Gujo, F. (2019). Assessment on Observance of Essential Conditions of Marriage under Customary Marriage of Sidama, Southern Ethiopia. Beijing Law Review, 10, 62-76. 
https://doi.org/10.4236/blr.2019.101004

Jadesimi v Okotie-Eboh \& two Ors (1996) 2NWLR (Pt 429) 128.

Krenawia, A. (2004). Family Theraphy with Multiple Parental and Multi-Spousal Family. Family Process, 37, 61-81.

Mclntosh, C. (2013). Cambridge Advance Learners Dictionary (4th ed., p. 948). Cambridge University Press.

Merriam-Webster Dictionary. https://www.Merriam-webster.com/dictionary/marriage

Morgan, C. (1965). The Interaction of English and Customary Law in Western Nigeria. Being a Lecture Delivered at the Ahmadu Bello University on 18th January.

Nwagbara, I. (2004). Recognition of Polygamous Marriages under the English Law. Global Journal of Politics and Law Research, 2, 52-62.

Nwogugu, E. I. (1985). Family Law in Nigeria. Heinemann Educational Books Nigeria Ltd.

Odive v Nwaeke Obor \& ors (1973) ECSNLR 733.

Ogunmodede v Thomas (1962) Supreme Court FSC337.

Ohochuku v Ohochuku (1960) 1 ALLER 253.

Ojogbo, S. (2011). Judicial and Scholarship Dilemma in Statutory and Customary Law Divorce in Nigeria. Nigerian Law and Practice Journal, 10.

Okhaide, P. I. (2021). Legitimacy, Legitimation and Succession in Nigeria: An Appraisal of Section 42(2) of the Constitution of the Federal Republic of Nigeria 1999 as Amended on the Rights of Inheritance. Journal of Law and Conflict Resolution, 4, 31-44.

Okoro, G. U., \& Wesey, A. U. S. (2014). Double-Decker Marriage in Different Jurisdictions. In Presentation to LLM Class, 2013/2014 Session of Faculty of Law. https://www.academia.edu/10197380/DOUBLE DECKER MARRIAGES

Olokooba, S. M. (2007). Analysis of Legal Issues Involved in the Termination of the "Double-Decker Marriage" under the Nigerian Law (pp. 194, 196). Nigeria Current Law Report, 2007-2010.

Onoka, M. C. (2003). Family Law. Spectrum Books Ltd.

Oseni v Oseni 1972 in Sagay I., Nigerian Family Law: Principle, Statutes and Commentaries $[n]$ p. 831.

Osho \& Ors. v Philips \& Ors, 1972 JELR44113 (SC) or SC180/1969, 30 March, 1972.

Oxford Languages and Goggle. https://languages.oup.com/goggle-dictonary-en/marriage

Sagay, I. (1999). Nigerian Family Law: Principles, Statutes and Commentaries. Malthouse Law Books.

Teriba v Teriba \& Rikette (1969) Suit no 1/211/57 of 2nd July, (unreported) Ibadan High Court.

The Criminal Code Cap 38 Laws of the Federation of Nigeria, 2004, s2.

The Evidence Act, 2011.

The Marriage Act Cap M6, Laws of the Federation of Nigeria 2004.

The Matrimonial Causes Act Cap M 7, Laws of the Federation of Nigeria 2004. 